\title{
Madelung's disease as a rare cause of obstructive sleep apnea*,**
}

\author{
Doença de Madelung como causa rara de apneia obstrutiva do sono \\ Vitor Alexandre Oliveira Fonseca, Carlos Alves, \\ Helena Marques, Elvira Camacho, António Pinto Saraiva
}

\begin{abstract}
Madelung's disease, or multiple symmetric lipomatosis, is a rare disease, characterized by accumulation of unencapsulated fat, generally located symmetrically around the neck and shoulders. Here, we present the case of a patient with diffuse lipomatosis accompanied by obstructive sleep apnea due to cervical involvement and facial deformity, which made it necessary to use nasal pillows for ventilation. The patient was hospitalized with a diagnosis of pneumonia and required noninvasive ventilation due to severe hypercapnia. A brief review of the literature was made, and we describe and discuss the investigation of this rare clinical case.
\end{abstract}

Keywords: Lipomatosis, multiple symmetrical; Sleep apnea, obstructive; Continuous positive airway pressure; Masks.

\section{Resumo}

A doença de Madelung ou lipomatose simétrica múltipla é uma doença rara, caracterizada pelo acúmulo de tecido adiposo não-encapsulado, localizado simetricamente ao redor do pescoço e na região escapular. Os autores apresentam um caso de associação entre lipomatose difusa e apneia obstrutiva do sono, devido ao envolvimento cervical e à deformação facial que exigiu a utilização de almofadas nasais para a ventilação. 0 doente foi admitido com o diagnóstico de pneumonia com necessidade de ventilação não-invasiva devido à hipercapnia grave. É apresentada uma breve revisão da literatura, e descrevemos e discutimos a investigação clínica deste raro caso clínico.

Descritores: Lipomatose simétrica múltipla; Apneia do sono tipo obstrutiva; Pressão positiva contínua nas vias aéreas; Máscaras.

\section{Introduction}

Madelung's disease or multiple symmetric lipomatosis is a rare disease, which is characterized by accumulation of unencapsulated fat, generally located symmetrically around the neck and shoulders. The disease was first documented in 1846 by Brodie, who was followed by Madelung in 1888 and by Launois \& Bensaude in 1898. ${ }^{(1,2)}$ It has been referred to by other names, such as lipoma anulare colli, morbus Launois-Bensaude, horse collar, multiple symmetric lipomatosis and benign symmetric lipomatosis. In patients with masses increasing the neck diameter, the disease gradually assumes the appearance of a horse collar. ${ }^{(2)}$ Although the etiology is unknown, it is often seen in patients with a history of chronic alcoholism, and it is usually accompanied by hyperuricemia, dyslipidemia, macrocytic anemia, peripheral neuropathy, glucose intolerance, renal tubular acidosis and alcohol use. ${ }^{(3-5)}$ These fatty masses cause facial disfigurement and are accompanied by digestive and respiratory symptoms. Most patients with Madelung's disease present reduced neck mobility, limited opening of the mouth and compression of vital structures, causing serious problems with respiration and orotracheal intubation. Symptomatic

\footnotetext{
* Study carried out in the Department of Pulmonology, Hospital Nossa Senhora do Rosário - HNSR - Barreiro, Portugal. Correspondence to: Vitor A. 0. Fonseca. Av. Movimento das Forças Armadas, s/n, 2830-094, Barreiro, Portugal.

Tel 3512121473 00. E-mail: vitor_fonseca@sapo.pt

Financial support: None.

Submitted: 2 March 2009. Accepted, after review: 10 August 2009.

** A versão completa em português deste artigo está disponível em www.jornaldepneumologia.com.br
} 
extrinsic compression or dislocation of internal structures such as the trachea have been described. ${ }^{(5)} A$ large neck circumference probably reflects greater deposition of fat and soft tissue, which is more significantly associated with sleep apnea. ${ }^{(6,7)}$

This condition mainly affects males between 30 and 60 years of age, the male/female ratio ranging from $15: 1$ to $30: 1{ }^{(8)}$ and its prevalence is higher in the Mediterranean area. ${ }^{(9)}$ Although the real incidence of the disease is unknown, it is usually considered to be very low, only 200 cases having been reported to date. However, some authors believe that the prevalence of the disease might be higher in some populations; for instance, among males in ltaly, the incidence rate is estimated to be $1 / 25,000 .^{(10)}$

In patients with Madelung's disease, the therapeutic possibilities are limited and the chances for success are low. The lipomas are unresponsive to dietetic intervention or the cessation of alcohol consumption, and they show no tendency toward regression. (11) The standard treatment is surgical excision or liposuction. ${ }^{(12,13)}$ The results are often unsatisfactory because of the sheer number of lipomas and quite frequent relapses. ${ }^{(11)}$ Since obesity is often accompanied by obstructive sleep apnea, ${ }^{(14-16)}$ it seems reasonable to suspect sleep apnea in patients with Madelung's disease, daytime sleepiness and fatigue. ${ }^{(16)}$ In a recent study conducted in Brasil, ${ }^{(17)} 300$ patients with sleep apnea were evaluated, 271 (90.3\%) of whom were considered overweight or obese. The authors found that body mass index was the clinical parameter that had the greatest impact on the severity of the disease (apnea-hypopnea index, percentage of total sleep time spent in apnea and minimum $\mathrm{SpO}_{2}$ ). Intermittent nocturnal hypoxemia has been also extensively studied in patients with obstructive sleep apnea syndrome (OSAS), as well as in experimental models, and has been strongly associated with numerous dysfunctions that affect such patients, such as cardiac abnormalities, muscle abnormalities, pulmonary arterial hypertension, peripheral neuropathy and autonomic abnormalities, all of which are associated with decreased exercise capacity, ${ }^{(18)}$ lower productivity and greater morbidity.

Quoting Martinez, ${ }^{(19)}$ "Managing patients with [OSAS] has the potential to reduce the billions of dollars in material damages and to avoid

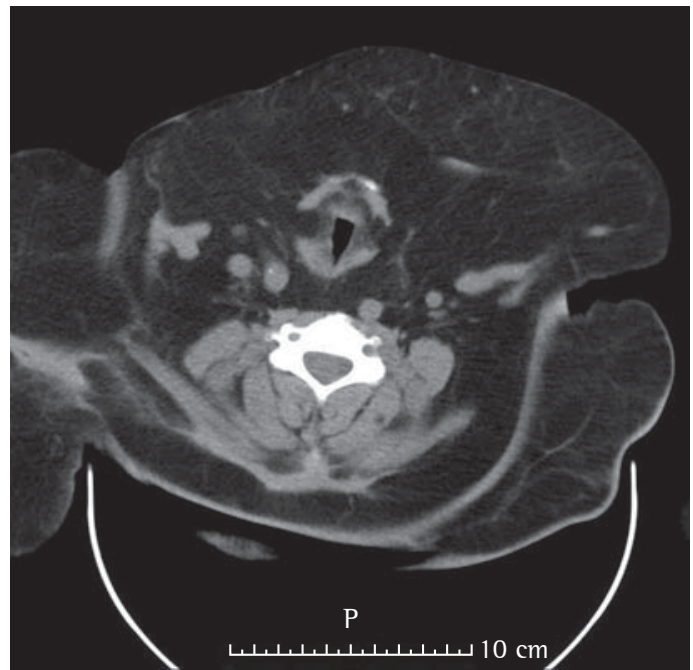

Figure $\mathbf{1}$ - Cervical CT scan showing areas of fat deposition, causing a reduction in the oropharyngeal diameter (less than $1 \mathrm{~cm}$ in the anteroposterior measurement and $2 \mathrm{~cm}$ in the transversal measurement).

untimely deaths. Pulmonologists, maintaining their tradition of combating dreaded diseases, such as tuberculosis, as well as those that are insidious, such as smoking, should be challenged to transform OSAS from a still unknown disease into a treatable cause of morbidity and mortality for patients and bystanders."

Here, we present a case of diffuse lipomatosis associated with obstructive sleep apnea

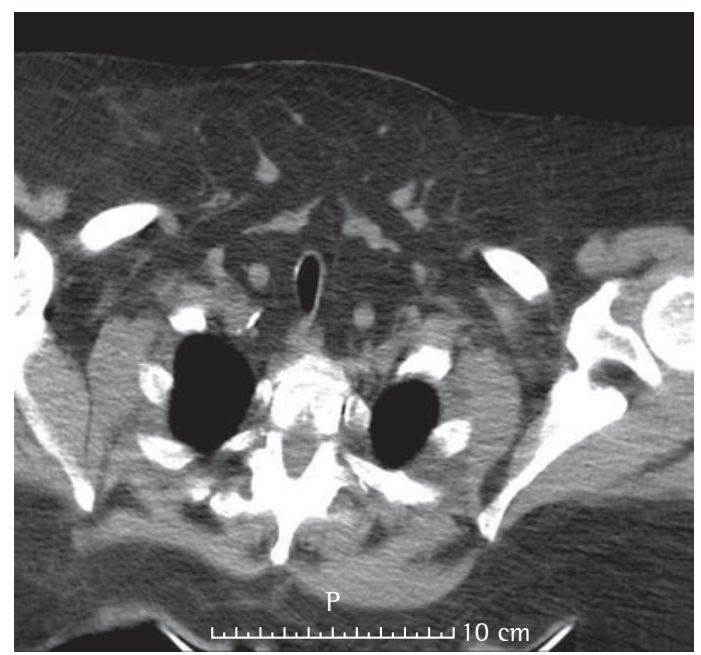

Figure $\mathbf{2}$ - Cervical CT scan showing areas of fat deposition in the mediastinum, causing a reduction in the trachea caliber of $1 \mathrm{~cm}$ transversally and $4 \mathrm{~cm}$ anteroposteriorly. 


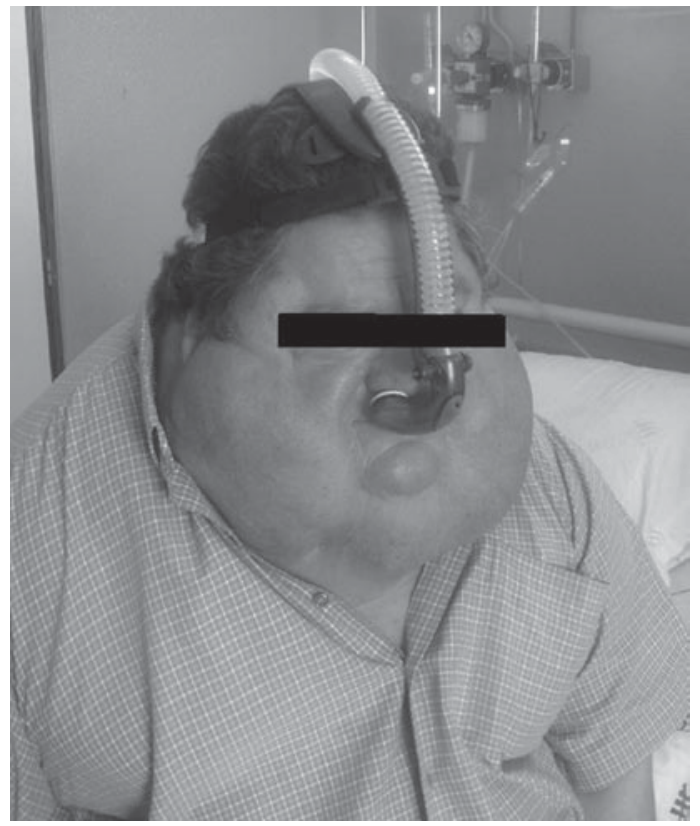

Figure 3 - Large masses around the neck, causing facial deformity. Nasal pillows were used for ventilation.

due to cervical and tracheal involvement, and with facial deformity causing problems in the patient's adaptation to noninvasive ventilation.

\section{Case report}

A 62-year-old white male, admitted to the ER with complaints of cough, sputum production and progressive dyspnea for 30 days. He had been diagnosed with Madelung's disease at the age of 30, having undergone plastic surgery for lipoma removal on numerous occasions. He also had a history of diabetes, alcohol abuse, chronic liver disease and esophageal varices. The patient had been submitted to elective splenectomy five years prior and required invasive mechanical ventilation for 2 days in the ICU. The patient was tachypneic and cyanotic at admission, with an $\mathrm{SpO}_{2}$ of $84 \%$. A chest $\mathrm{X}$-ray revealed a diffuse bilateral infiltrate without evident consolidation.

The blood gas analysis showed $\mathrm{PaCO}_{2}$ of $64 \mathrm{mmHg}, \mathrm{PaO}_{2}$ of $49 \mathrm{mmHg}$ and normal $\mathrm{pH}$. The patient also presented with high acute inflammatory parameters, leukocytosis and high C-reactive protein levels, suggestive of a respiratory infection.

Admitted to the respiratory ward, the patient started treatment with antibiotics and was submitted to continuous bilevel positive air pressure (BiPAP) ventilation, demanding high level pressures to maintain $\mathrm{SpO}_{2}>90 \%$ and to normalize $\mathrm{PaCO}_{2}$-inspiratory positive air pressure (IPAP): $24 \mathrm{cmH}_{2} \mathrm{O}$; expiratory positive air pressure (EPAP): $8 \mathrm{cmH}_{2} \mathrm{O}$.

The clinical status of the patient progressively improved, with subsequent reduction in BiPAP pressures and in the use of the ventilator, which was interrupted on post-admission day 6 due to the appearance of facial ulcerations caused by the nasal mask. During the first night without noninvasive ventilation, there were long periods of oxygen desaturation $\left(\mathrm{SpO}_{2}<88 \%\right)$ and snoring. The patient was then submitted to cervicofacial CT (Figures 1 and 2) and a cardiorespiratory sleep study.

The sleep study lasted approximately $8 \mathrm{~h}$, revealing severe obstructive sleep apnea (apneahypopnea index: 37 events/h; obstructive apnea index: 29 events/h; median oxygen saturation during sleep: 88\%; oxygen desaturation index: 51\%/h; and minimum $\mathrm{SpO}_{2}: 51 \%$ ). The CT scan revealed various areas of fat deposition in the mediastinum, causing a reduction in the trachea caliber of $1 \mathrm{~cm}$ transversally and $4 \mathrm{~cm}$ anteroposteriorly. Continuous positive airway pressure (CPAP) titration was carried out on the second night, and the patient was discharged. At home, the patient remained on BiPAP ventilation (EPAP: $8 \mathrm{cmH}_{2}$ 0; IPAP: $16 \mathrm{cmH}_{2} 0$ ), delivered via nasal pillows (Figure 3).

The cardiorespiratory sleep study was repeated four weeks later, and the results confirmed the diagnosis of severe OSAS, with values similar to those obtained in the first sleep study.

\section{Discussion}

In the present case, the lipomas caused an enlargement of the neck circumference and a symptomatic reduction in the trachea diameter with airway impairment, especially during the night, causing several obstructive sleep apnea events. Since this patient had a history of plastic surgery with recurrence of the lipomas, a surgical solution was not the first choice of treatments, the use of CPAP being preferred.

The facial deformity, which impaired the use of nasal or facial masks, presented a considerable challenge. During the first days on the ward using a nasal mask, the patient presented multiple facial lesions and skin ulceration. The 
solution was to use nasal pillows, which increase comfort with a lower risk of leaks, promoting adherence of the patient to the treatment.

In our review of the literature (Medline), we found only a few case reports of patients with Madelung's disease and OSAS, ${ }^{(20-23)}$ confirming the rarity of this clinical situation and alerting us to the need for sleep screening in patients with Madelung's disease due to the risk of OSAS.

\section{References}

1. Launois PE, Bensaude R. De L'adenolipomatose Symetrique. Bull Membres Soc Med Hosp Paris. 1898;1:298.

2. Keller SM, Waxman JS, Kim US. Benign symmetrical lipomatosis. South Med J. 1986;79(11):1428-9.

3. Amicucci G, Sozio ML, Rizzo FM, Sozio A. Madelung's disease. Clinical case and review of the literature [Article in Italian]. Minerva Chir. 1998;53(7-8):655-7.

4. Gabriel YA, Chew DK, Wedderburn RV. Multiple symmetrical lipomatosis (Madelung's disease). Surgery. 2001;129(1):117-8.

5. Teplitsky V, Huminer D, Dux S, Learman Y, Zoldan J, Pitlik SD. Multiple symmetric lipomatosis presenting with polyneuropathy. lsr J Med Sci. 1995;31(11):693-5.

6. Schäfer H, Pauleit D, Sudhop T, Gouni-Berthold 1, Ewig S, Berthold HK. Body fat distribution, serum leptin, and cardiovascular risk factors in men with obstructive sleep apnea. Chest. 2002;122(3):829-39.

7. Tangerina Rde $P$, Martinho FL, Togeiro SM, Gregório LC, Tufik S, Bittencourt LR. Clinical and polysomnographic findings in class 111 obese patients. Braz J Otorhinolaryngol. 2008;74(4):579-82.

8. Gemperli R, Pigossi Jr 0, Ferreira MC, Lodovici 0. Tratamento cirúrgico da lipomatose simétrica múltipla: doença de Madelung. Rev Paul Med. 1988;106(6):313-6.

9. Guilemany JM, Romero E, Blanch JL. An aesthetic deformity: Madelung's disease. Acta Otolaryngol. 2005;125(3):328-30.

10. Enzi G. Multiple symmetric lipomatosis: an updated clinical report. Medicine (Baltimore). 1984;63(1):56-64.
11. Ruzicka T, Vieluf D, Landthaler M, Braun-Falco O. Benign symmetric lipomatosis Launois-Bensaude. Report of ten cases and review of the literature. J Am Acad Dermatol. 1987;17(4):663-74.

12. Brackenbury ET, Morgan WE. Surgical management of Launois-Bensaude syndrome. Thorax. 1997;52(9):834-5.

13. Dusková M, Topinka H. Lipomatosis benigna symmetrica-syndrome Launois-Bensaude (case report). Acta Chir Plast. 1994;36(2):61-3.

14. Grunstein RR. Metabolic aspects of sleep apnea. Sleep. 1996;19(10 Suppl):S218-20.

15. Sleep-related breathing disorders in adults: recommendations for syndrome definition and measurement techniques in clinical research. The Report of an American Academy of Sleep Medicine Task Force. Sleep. 1999;22(5):667-89.

16. Martins AB, Tufik S, Moura SM. Physiopathology of obstructive sleep apnea-hypopnea syndrome. J Bras Pneumol. 2007;33(1):93-100.

17. Knorst MM, Souza FJ, Martinez D. Obstructive sleep apnea-hypopnea syndrome: association with gender, obesity and sleepiness-related factors. J Bras Pneumol. 2008;34(7):490-6.

18. Mueller Pde T, Gomes MD, Viegas CA, Neder JA. Systemic effects of nocturnal hypoxemia in patients with chronic obstructive pulmonary disease without obstructive sleep apnea syndrome. J Bras Pneumol. 2008;34(8):567-74.

19. Martinez D. Obstructive sleep apnea: a contagious disease? J Bras Pneumol. 2006;32(2):ix-x.

20. Truy E, Léger P, Kauffmann 1, Deloste JY, Robert D, Morgon A. Launois-Bensaude disease and sleep apnea syndromes. Apropos of a recent case [Article in French]. Ann Otolaryngol Chir Cervicofac. 1993;110(8):474-7.

21. Harsch IA, Schahin SP, Fuchs FS, Hahn EG, Lohmann T, Konturek PC, et al. Insulin resistance, hyperleptinemia, and obstructive sleep apnea in Launois-Bensaude syndrome. Obes Res. 2002;10(7):625-32.

22. Mégevand C, Savoy J, Boudrama A, Meier D. Madelung disease and obstructive sleep apnea syndrome: apropos of a case [Article in French]. Schweiz Med Wochenschr Suppl. 2000;116:123S-126S.

23. Ali S, Kishore A. Dysphagia and obstructive sleep apnoea in Madelung's disease. J Laryngol Otol. 2007;121(4):398-400.

\section{About the authors}

\section{Vitor Alexandre Oliveira Fonseca}

Intern. Complementary Internship Program in Pulmonology, Hospital Nossa Senhora do Rosário - HNSR - Barreiro, Portugal.

\section{Carlos Alves}

Attending Pulmonologist. Hospital Nossa Senhora do Rosário - HNSR - Barreiro, Portugal.

\section{Helena Marques}

Attending Pulmonologist. Hospital Nossa Senhora do Rosário - HNSR - Barreiro, Portugal.

\section{Elvira Camacho}

Head of the Department of Pulmonology. Hospital Nossa Senhora do Rosário - HNSR - Barreiro, Portugal.

\section{António Pinto Saraiva}

Head of the Department of Pulmonology. Hospital Nossa Senhora do Rosário - HNSR - Barreiro, Portugal. 